* Corresponding author Phone +421556023547 E-mail address: emil.evin@tuke.sk (E. Evin)

Article information

Article history: AMS-Volume15-No.1-00104-11 Received 18 March 2011

Accepted 11 May 2011

Available online 26 August

\section{Desing of Dual Phase Steel Sheets for Auto Body}

\author{
Evin Emil a* \\ a Department of Technologies and Materials, Faculty of Mechanical Engineering, Technical University of Košice, Mäsiarska 74, 04001 Košice, \\ Slovak Republic
}

\section{BIOGRAPHICAL NOTES}

prof. Ing. Emil Evin, CSc. (born 1956) is a professor in the scientific area of Engineering Technologies and Materials, Faculty of Mechanical Engineering at the Technical University in Kosice. He graduated the Faculty of Mechanical Engineering, Technical University of Kosice (1980). He was inaugurated as a professor in 2010 with his work "Verification of numerical simulation of formability of high strength steel sheets" in the field of Mechanical Engineering Technologies and Materials. Prof. Evin pass through the study and lecture stays in Technische Hochshule Zwickau, Technical University in Kielce, Technical Universities in Maribor and Ljubljana; and Technical University in Chemnitz. Long term, his scientific and research activities are oriented to the field of technological prediction of formability of steel sheets with higher strength properties, testing of material properties of steel sheets, simulation of stamping processes, the evaluation of the technicaleconomic level of production and engineering products. Prof. Evin was the principal investigator of 3 VEGA projects, co-partner of several national and international scientific research projects and dozens of projects for practice. His activities in the Technical University in Košice: Deputy of Head of Department, member of the Common Branch Committee "Mechanical Engineering Technologies and Materials", a member of the Faculty Commission "Mechanical Engineering Technologies and Materials" Examination Commission for a doctoral level of study at the MTF STU Trnava, expert and judge (reviewer) of the Slovak National Accreditation Service. He is co-author of one monograph, 5 university textbooks, over 180 original scientific papers published in domestic and foreign journals and proceedings.

\section{KEY WORDS}

Desing, Dual Phase, Steel Sheets, Strenght, Energy Absorbing, Deep Drawing Capacity, Stretching Capacity

\footnotetext{
ABSTRACT

This paper outlines the considerations of strength and energy absorbing car body by applying mechanical properties of steel sheets with higher strength properties. Good combination of strength and ductile properties of dual-phase steel helps reduce weight and improve crash safety body. High-strength dual-phase steels have better deep-drawing capacity and stretching capacity compared to microalloyed at the same strength. Dual phase steel sheet have comparable streching capacity but poorer deep drawing capacity than DC04. Measured values LDR and FLD0 have to serve engineers who haven't experience with application of high strength steel sheets for car body.
} 


\section{Introduction}

To reduce the specific consumption of rolled steel with an increase of the volume of production of products from sheets in engineering and other areas of national economy it is necessary to ensure qualitative changes associated with higher applied properties of final sheet products. One of the methods of increasing the applied properties of sheet products is to use steel sheets with higher strength properties enabling the wall thickness of pressings to be reduced thus obtain the required material saving without affecting the strength and functional properties of sheet products, and the com $\neg$ peting capacity of steel sheets in comparison with other types of materials can also be improved (Hrivñák et al., 2004).

Advantage of steel sheets as construction material is that by application of steel sheets with higher strength properties $-\mathrm{Re}>210 \mathrm{MPa}$ (IF steels, BH steels, dual phase $\mathrm{F}-\mathrm{M}$ or $\mathrm{F}-\mathrm{B}$, multiphase, martensitic steels, austenitic steels the required reliability (strength, stiffness, impact resistance and etc.) of construction elements it is possible to obtain not only by the way of increasing the wall thickness of stamped part (sheet thickness), but also by reduction of wall thickness (mass) of stamped part and shape complexness of construction element. The required combination of strength-plastic propertiesof high strength steels for for cold forming, it can be predicted by Hall Petch relationship as the additive effect of the various mechanisms of hardening (Parilák et al., 1988).

Steel sheets which fulfill these requirements include dual-phase ferritic-martensitic $(\mathrm{F}-\mathrm{M})$ steels. The dualphase $\mathrm{F}-\mathrm{M}$ steels are characterized by a fine-grained ferrite matrix with uniformly distributed martensite islands. The ductility properties are ensured by the finegrained ferritic matrix and the strength properties by the volume proportion of martensite in the structure and by the strength of the ferritic matrix which depends mainly on the ferrite grain size.
The ferrite matrix can be refined by microalloying with $\mathrm{V}, \mathrm{Ni}$, Ti and by controlled rolling. As a result of forming precipitates microalloying elements harden the ferrite matrix at the expense of the ductility properties. The precipitation processes must be controlled in such a manner as to ensure that the steel sheets to be used for cold forming have the required formability with the highest possible strength properties (Aksoy et al., 1996; Evin, 2006; Rosenberg et al., 2009; Hanssen, 1982).

\section{Experimental Procedure}

Experimental research for evaluating the strength and energy absorption and formability of sheets with higher strength properties was carried out on steels sheets of $\mathrm{F}-\mathrm{M}$ produced by intercritical annealing (specimens designated A,B,C,D,E,F) and specimens by the method of controlled rolling (specimens denoted as $\mathrm{G}, \mathrm{H}, \mathrm{I}, \mathrm{J}, \mathrm{K}$ ).

The volume proportion of the individual structural components and the ferrite grain size are in Table 1. Metallographic analysis of the materials A,B,C,D,E,F show that they have a fine-grained ferrite-martensite structure with martensite dispersion excluded in the form of small islands which form mainly in the area of the ferrite grain boundaries (Fig. 1). In the material G,H,I,J,K martensite formed large islands and ferrite and martensite grains 'alternated' (Fig. 2) (Evin, 2006).

The materials $\mathrm{G}$ and $\mathrm{H}$ had a dual-phase structure. In many cases the second phase showed a morphological feature of martensite or a mixed nonpolyhedral structure.

Based on the brief analysis of the metallo-graphic structure it may be concluded that a large difference was detected in the morphology on distribution of martensite in the materials produced by intercritical annealing (A,B,C,D,E,F) in comparison with the materials produced by controlled rolling $(\mathrm{G}, \mathrm{H}, \mathrm{I}, \mathrm{J}, \mathrm{K})$.

Table 1: Volume fraction of the individual structural components.

\begin{tabular}{|c|c|c|c|c|c|c|c|c|c|c|c|}
\hline Method of production & \multicolumn{6}{|c|}{ Intercritical annealing } & \multicolumn{5}{|c|}{ Controlled rolling } \\
\hline Designation of material & \multicolumn{3}{|c|}{ A } & \multicolumn{2}{|c|}{$D, E$} & & & & $\mathrm{~F}$ & & \\
\hline Designation of specimens & A & B & C & D & E & F & G & $\mathrm{H}$ & । & J & K \\
\hline $\begin{array}{l}\text { Volume fraction of } \\
\text { martensite (\%) }\end{array}$ & 19,9 & 25,4 & 20,3 & 27,9 & 31 & 31 & 25 & 52 & 25 & 27 & 29 \\
\hline $\begin{array}{l}\text { Volume fraction of ferrite } \\
\qquad(\%)\end{array}$ & 80,1 & 74,6 & 79,7 & 72,1 & 69 & 69 & 75 & 48 & 75 & 73 & 71 \\
\hline Ferrite grain size ( $\mu \mathrm{m})$ & \multicolumn{5}{|c|}{$3,1-4,3$} & \multicolumn{6}{|c|}{$3,6-4,5$} \\
\hline
\end{tabular}




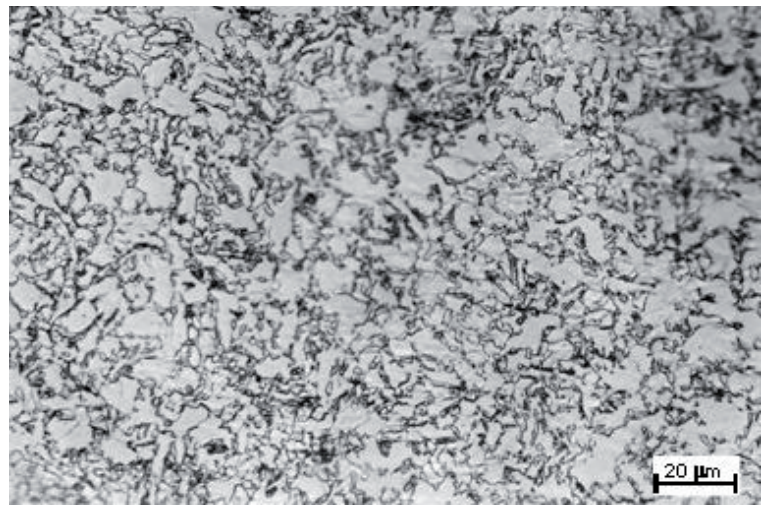

Fig. 1: Structure of material $A$.

To obtain the material properties the tensile machines TIRATEST 2300 and INSTRON were used. Curves of dependence of true stress on strain, normal anisotropy coefficient, yield strength, tensile strength and total elongation were evaluated in the sence of requirements of standars STN EN 10 002-1, STN EN 42 0435, EN 10130:1991. Values of mechanical properties are given in Table 2.

Higher values of yield strength and elongation in-

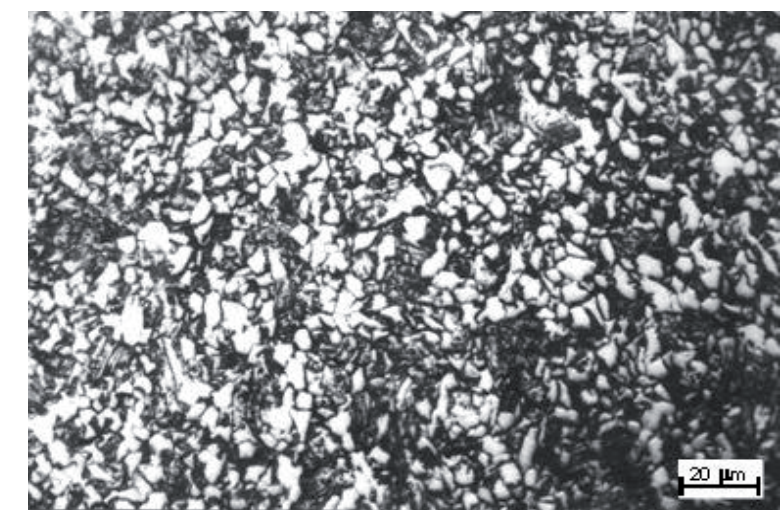

Fig. 2: Structure of material G.

dicate good strength and energy absorption of steel sheets. Low values of yield strength, higher values of elongation, normal anisotropy coefficient and exponent of strain hardening indicate the good formability. High-strength steel sheets with tensile strength in the range from $400 \mathrm{MPa}$ to $800 \mathrm{MPa}$ cannot be classified according to conventional schemes of evaluation of formability because these steels despite their higher strength show good formability (Evin, 2006; Hanssen, 1982).

Table 2: Mechanical properties.

\begin{tabular}{|c|c|c|c|c|c|c|}
\hline Material & $\begin{array}{l}\text { Yield } \\
\text { strength } \\
\text { Re [MPa] }\end{array}$ & $\begin{array}{c}\text { Tensile } \\
\text { strength } \\
\text { Rm [MPa] }\end{array}$ & $\begin{array}{c}\text { Total } \\
\text { elongation } \\
\text { A50 [\%] }\end{array}$ & $\begin{array}{c}\text { Strain- } \\
\text { hardening } \\
\text { exponent } n\end{array}$ & $\begin{array}{c}\text { Constant } \\
\text { K } \\
{[\mathrm{MPa}]}\end{array}$ & $\begin{array}{l}\text { Plastic strain } \\
\text { ratio r }\end{array}$ \\
\hline DC 04 & 210 & 350 & 40 & 0,2 & 470 & 1,6 \\
\hline A & 299 & 593 & 31 & 0,229 & 1076 & 1,01 \\
\hline B & 361 & 647 & 26 & 0,196 & 1113 & 1,03 \\
\hline C & 304 & 596 & 30 & 0,211 & 1052 & 1,05 \\
\hline D & 361 & 646 & 24 & 0,18 & 1073 & 1,04 \\
\hline E & 443 & 792 & 22 & 0,184 & 1336 & 0,71 \\
\hline $\mathbf{F}$ & 437 & 791 & 22 & 0,166 & 1270 & 0,82 \\
\hline G & 460 & 646 & 24 & 0,166 & 1070 & 0,81 \\
\hline H & 492 & 733 & 15 & 0,13 & 1153 & 0,63 \\
\hline I & 464 & 624 & 23 & 0,167 & 1085 & 0,82 \\
\hline $\mathbf{J}$ & 458 & 656 & 27 & 0,172 & 1070 & 0,671 \\
\hline K & 495 & 627 & 21 & 0,165 & 1080 & 0,78 \\
\hline
\end{tabular}

It is recommended to use a number of simulation tests, for more detailed evaluation of the suitability of steel sheets for deep-drawing and stretching, in addition to the mechanical properties, for example, extrusion according to the Swift cup test, the Erichsen cup test, Bulge test, the Goodwin-Keller criterion of the limiting curves of deformation, etc., which enable simulate loading of the material in forming operations. For evaluation of the suitability of dual phase steel sheets for deep-drawing was used Swift cup test. 
The limiting drawing degree

$$
L D R=\frac{\text { max imum blank diameter }}{\text { punch diameter }}=\frac{D_{\max }}{d}
$$

as a technological measure of deep-drawing capacity is calculated according to equation (1). LDR was determined in pilot plant conditions of deep-drawing cylindrical drawn products with a flat bottom in a BZE 1000 hydraulic press and in a universal drawing tool with a drawing die diameter of $75 \mathrm{~mm}$, the radius of curvature of the drawing edge of the die $r_{p}=5 \mathrm{~mm}$ and the drawing tool $r_{t}=5 \mathrm{~mm}$, using lubricant Anticorit.

\section{Duscusion of Obtained Results}

Based on experiences of designers it is possible to define the requirements for materials from the viewpoint of static strength and energy absorption reliability (Šimčák, 2002). Effectiveness of static strength

$$
E S T=\frac{\mathrm{Re}}{\operatorname{Re}_{D C 04}} 100[\%]
$$

Effectiveness of energy absorption

$$
E E A=\frac{\frac{(\mathrm{Re}+R m)}{2} \cdot A_{50}}{\frac{\left(\operatorname{Re}_{D C 04}+R m_{D C 04}\right)}{2} \cdot A_{50, D C 04}}[\%]
$$

where: $\mathrm{R}_{\mathrm{p} 0,2}$ or $\mathrm{Re}$ is yield strength, $\mathrm{Rm}$ tensile strength, $\mathrm{A}_{50}$ total elongation.

Comparison of the mechanical properties specified in the material of the sheets of the material DC 04 with the measured values obtained for the examined materials of the $\mathrm{F}-\mathrm{M}$ steels (Table 2 ) show that the yield limit ( $\mathrm{Re}=299-495 \mathrm{MPa})$ and the tensile strength ( $\mathrm{Rm}=593-792 \mathrm{MPa})$ of all materials was higher that of a mild steel DC 04. Approximately the same volume fraction of martensite in the structure the materials produced by intercritical annealing had lower yield limit values than the materials produced by controlled rolling. The elongation values (A50 $=15-$ $31 \%$ ) of specimens A, C, G1, G2, G3, H3, H4 varied in the range of materials suitable for slight drawing or bending and for other materials in the range of materials unsuitable for deep-drawing. As in the case of strength, the elongation values showed no large difference between the materials produced by intercritical annealing and the materials produced by controlled rolling.

Calculated values of the effectiveness of static strength and energy absorption according to equation $(2,3,6)$ for high strength dual phase steels has been compared to the steel sheets DC 04 - Fig. 3. These results indicate the potential for weight reduction from 42 to $135 \%$ with equivalent energy absorption.

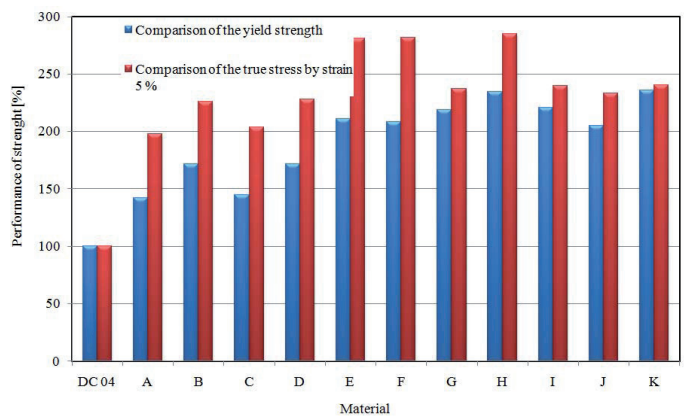

Fig. 3: Comparison of strength of materials tested with referencematerial DC 04

As it was mentioned the most of the inner bearing construction elements of car body are made of steel sheets. These elements are produced by operations of bending, stretching and deep drawing. During bending deformation occurs to the deformation hardening only in small part of bend (in local deformation) of stamped part, in non deformed parts (in straight parts of stamped part) deformation-strain hardening doesn't occurs. Stamped parts produced by bending show non-homogenous distribution of deformation. During deep-drawing and stretching operation occurs to deformation of the stamped parts on whole area, and also to strain hardening. More homogenously is deformation distributed at stretching as at deep drawing. It is required to calculate with strain hardening but also with interstitial hardening (BH effect- increasing the strength about approximately 30 to $60 \mathrm{MPa}$ ), to optimize the material selection, that increase the strength.

Effect of strain hardening can be approximated by a power law constitutive equation (4):

$\sigma=K \cdot \varepsilon^{n}$

The exponent of strain hardening of the material react very sensitively to the change in the condition of the structure and substructure of the material and enable the limit of the loss of plastic stability, reduction area, to be expressed more accurately. Up to this limit there is a guarantee that plastic deformation doesn't 
localize and there is no subsequent failure of the material.

Comparison of the constant $\mathrm{K}$ specified in the material of the sheets of the material DC 04 with the measured values obtained for the examined materials of the $\mathrm{F}-\mathrm{M}$ steels (Table 2) show that the constant $\mathrm{K}$ $(\mathrm{K}=1052-1336 \mathrm{MPa})$ of all materials was higher that of a steel sheets DC 04 and the values of the exponent of strain hardening of materials produced by intercritical annealing were greater or comparable with the DC 04. Materials produced by rolling have shown lower values of strain hardening exponent as DC 04 . Approximately the same volume fraction of martensite in the structure of materials produced by intercritical annealing had higher strain-hardening exponent and constant $K$ values than the materials produced by controlled rolling. The results confirmed the interaction effect of ferrite and martensite reflected in an increase of dislocation density in ferrite and at the ferrite-martensite boundary and in an increase in flow stress.

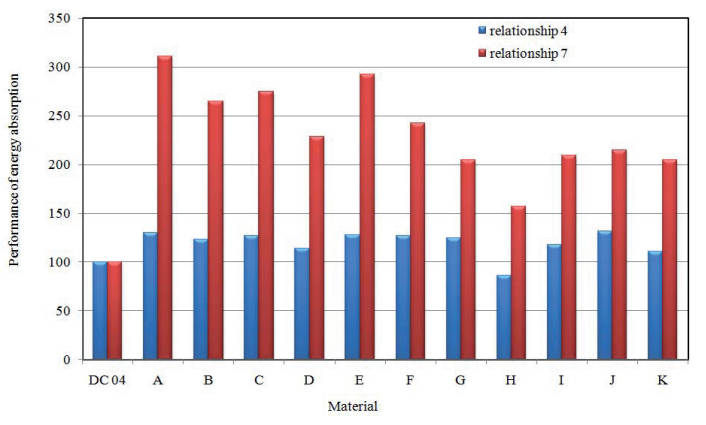

Fig. 4: Comparison of energy absorption of materials tested with reference material DC 04.

However, at assumption that at production of certain stamped part $5 \%(\varepsilon=0,05)$ deformation and true stress is expressed by relation (4), dual phases materials shows approximately from 100 to $200 \%$ higher strength as reference material DC 04 - Fig. 3. The increasing in fatigue strength is equivalent no matter if the increase of yield strength is due to work hardening. Boundary condition are crucial in determining the stain work, depending on the true stress versus true strain - Fig. 5. Then the strain work can be calculated according to equation (5):

$W=\int_{\varepsilon=0,05}^{e_{u}} K \cdot \varepsilon^{n}=\frac{K}{n+1}\left(\varepsilon_{e u}^{n+1}-\varepsilon_{0,05}^{n+1}\right)$

and effectiveness of energy absorption
$E E A=\frac{W}{W_{D C 04}} 100[\%]$

Dual Phase-steels exhibit of strain hardening effect, i.e. sustain higher stresses at increased deformation. This effect corresponds to increase in load car crash to the reference material - Fig. 4.

Suitability of dual phase steel sheets for deep drawing was evaluated based on values. recommended for qualitatative grades of drawing of classical steel sheets (deep drawing process - values LDR and stretching - values FLD0) Table 3. Values of limiting ratio (LDR) for examined material, evaluated by method of intercritical annealing, varied in the range from 2 to 2,07 and in materials produced by controlled rolling from 1,78 to 1,97 . We measured higher values of the degrees of the LDR in approximately the same volume fraction of martensite in structure of materials produced by controlled rolling. The diagram LDR Fig. 6 indicates that materials produced by intercritical annealing appear to be suitable for deep drawing (DDQ) whereas the materials produced by controlled rolling appear to be suitable for drawing quality (DQ).

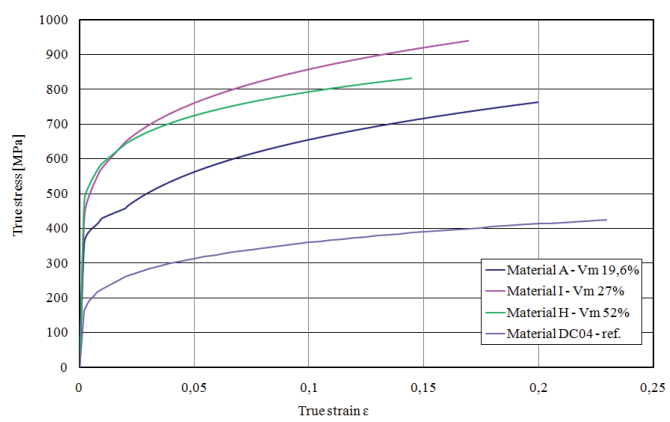

Fig. 5: Depend on the true stress versus true strain.

Sheet of DDQ quality should be used when drawing steel will not provide a sufficient degree of ductility for fabrication of parts with stringent drawing requirements, or applications that require the sheet to be free from aging. This quality is produced by special steelmaking and finishing practices. It is suitable for automotive front panels and rear fenders. Sheet of DQ quality has a greater degree of ductility and is more consistent in performance than commercial steel, because of higher standards in production, selection and melting of the steel. It is suitable for automotive panels, audio-visual equipment, and heating apparatuses. 
Table 3: Quality specifikation of steel sheets for deep drawing and stretching.

\begin{tabular}{|c|c|c|c|c|c|}
\hline \multirow[b]{2}{*}{ Classification } & \multirow[b]{2}{*}{ EN10130 } & \multicolumn{2}{|c|}{$\begin{array}{l}\text { Low specification limit (LSL) and } \\
\text { upper (USL) }\end{array}$} & \multicolumn{2}{|c|}{ Clasification used materials } \\
\hline & & $\begin{array}{c}\text { For deep } \\
\text { drawing } \\
\text { capacity - LDR }\end{array}$ & $\begin{array}{l}\text { For stretching } \\
\text { capacity - FLDO }\end{array}$ & $\begin{array}{l}\text { For deep } \\
\text { drawing } \\
\text { capacity }\end{array}$ & $\begin{array}{l}\text { For stretching } \\
\text { Capacity }\end{array}$ \\
\hline CQ (Commercial Quality) & DC01 (Fe P01) & $<1,8$ & & & $\mathrm{H}$ \\
\hline DQ (Drawing Quality) & DC03 (Fe P03) & $1,8-2$ & $<0,264$ & $\mathrm{G}, \mathrm{H}, \mathrm{I}, \mathrm{J}, \mathrm{K}$ & $\mathrm{G}, \mathrm{I}, \mathrm{J}, \mathrm{K}$ \\
\hline $\begin{array}{l}\text { DDQ-N (Stabilized Deep Drawing } \\
\text { Quality) }\end{array}$ & DC04 (Fe P04) & $2-2,2$ & 0,297 & $A, B, C, D, E, F$ & $B, D, E, F$ \\
\hline EDDQ Extra Deep Drawing Quality) & DC05 (Fe P05) & $2,2-2,3$ & $>0,33$ & & $A, C$ \\
\hline
\end{tabular}

Based on specification of LDR for classic deep-drawing steel, it is possible to specify requirements for the volume fraction of martensite $\mathrm{F}-\mathrm{M}$ steel sheets follows:

Extra deep drawing quality EDDQ: $V m<15 \%$

Deep drawing quality $D D Q: V m$ 15-35\%

Drawing quality $D Q: V m>35 \%$.

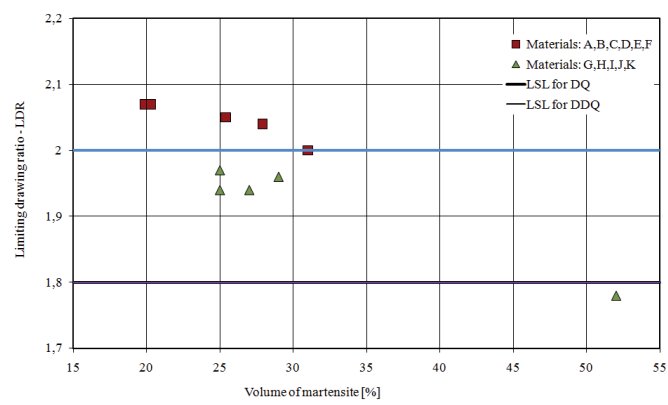

Fig. 6: Specification of limiting drawing ratio versus volume of martenzite.

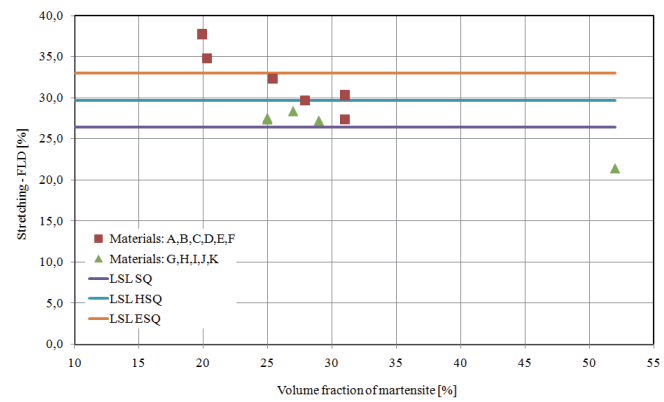

Fig. 7: Specification of stretching versus volume of martensite.

For the stress-strain states from uniaxial tension to biaxial tension (streching) are preferable to use Forming limiting diagrams - FLD. FLD indicate the limiting strain that sheet metals can sustain over range of major to minor strain ratios. Specially, there are several methods that can be used to compute the FLDs. In (Goffroy, 1998) is given relationship (7) for predicting FLD for different materials on the basis of thickness sheet and strain hardening exponent.

$$
F L D 0=\left(23,3+14,3 \cdot a_{0}\right) \frac{n}{0,21}[\%]
$$

In terms of suitability for stretching, materials with martensite dispersion excluded in the form of small islands are classified as - Fig. 7:

Extra stretching quality ESQ: Vm<15\%

High stretching quality HSQ: Vm $15-25 \%$

Stretching quality SQ: Vm $25-35 \%$

Commercial stretching quality CSQ: $\mathrm{Vm}>35 \%$.

\section{Conclusion}

Dual phase steel sheets represent progressive material, but constructors often do not know its advantages in comparison with classical steel sheets. In the article, debates about prediction of strenght, capability of the bodywork to absorb energy during crash accident and also formability (deep drawing capacity a stretching capacity) of dual phase ferit-martensite steels. Strenght of auto body and its capability to absorption energy was quantified based on comparison of mechanical properties of dual phase steel sheets to mechanical properties steel sheets DC 04. From this comparison one can see that dual phase steel have 42 and $135 \%$ higher values of strenght and also higher values of deformation work. In case of production of steel sheets by stretching with deformation higher than $5 \%$ the increasment of stress to $100-200 \mathrm{MPa}$ occurs. Formability of high strenght dual phase steels was compared to formability of deep-drawn steel DC 04. Deep drawing capacity steel DC 04 has better formability than dual phase steel, but differences were small in 
some cases (material A,B,D). Stretching capacity was compared with stretching capacity of dual phase steel sheets with volume fraction of martensite lower than $25 \%$. Dual phase steel sheets with fine ferit-martensite structure with martensite dispersion excluded in form of small islands in grains ferrite boundaries have higher values strenght and plastic properties as steel with martensite dispersion excluded in form of bigger islands. Values of forming limiting diagram decreasing with decreasing strain-hardenig exponent. For comparison, on the basis of limit drawing ratio there were determined conditions for quality deep drawings (CQ, DQ, DDQ, EDDQ) on volume fraction of martensite in structure and in the same similary also for stretching capacity (CSQ, SQ, HSQ, ESQ).

\section{Acknowledgement}

Knowledge presented in this contribution were obtained in the framework of the Grant project VEGA 10890/09.

\section{References}

Aksoy, M., Karamis, M.B., Evin, E. (1996). An evaluation of the wear behaviour of a dual-phase low-carbon steel. Wear, 193

Doege, E., Droder, K., Greisbach, B. (1997). On the Development of New Characteristic Values for the Evaluation of Sheet Metal Formability. Journal of Materials Processing Technology, vol, 71, no. 7

Evin, E. (2006) Tvárnitel'nost' vysokopevných ocelí a jej predikcia. TU, Košice

Goffroy, J.L. (1998). Validity of the FLDs calcoaltions. IDDRG Working Group 3

Hanssen, S.S. (1982). The formability of dual phase steel. Journal of applied metalworking, vol. 2, no. 2

Hrivňák, A., Evin, E. (2004). Lisovatelnost' plechov: Predikcia lisovatelnosti ocelových plechov s vyššími pevnostnými vlastnostami. ELFA, Košice

Parilák, L., Šlesár, M., Štefan, B. (1988). Proceedings of Microalloying' 88, Chicago, USA.

Rosenberg, G., Buríková, K., Juhár, L.. (2009). Modifikácia pevnostnoplastických vlastností mikrolegovaných ocelí prostredníctvom tepelného spracovania. Výrobné inžinierstvo, vol. 8, no. 3

Šimčák, F. (2002). Možnosti využitia nových ocelí v tenkostenných nosných konštrukciách. Acta Mechanica Slovaca, vol. 4, no. 2

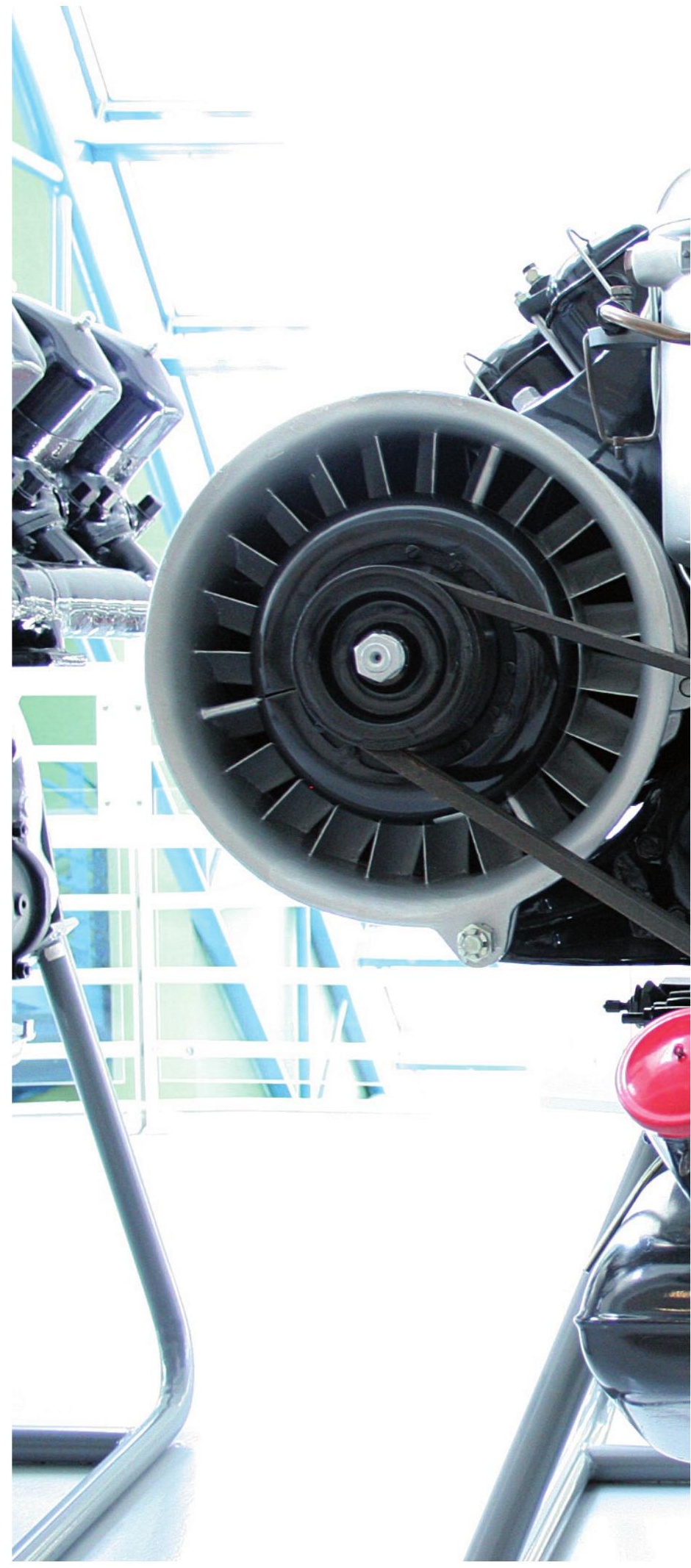

